\title{
A call to action: alcohol interventions in HIV-infected patients
}

\author{
Lorenzo Leggio $^{1 *}$, Kittichai Promrat ${ }^{2}$ and George A. Kenna ${ }^{1}$ \\ 1 Center for Alcohol and Addiction Studies, Brown University, Providence, RI, USA \\ 2 Division of Gastroenterology, Brown University, Providence, RI, USA \\ ${ }^{*}$ Correspondence: lorenzo_leggio@brown.edu
}

\section{A commentary on}

Case records of the Massachusetts General Hospital. Case 6-2012. A 45-year-old man with a history of alcohol abuse and rapid cognitive decline

by Cho, T. A., Larvie, M., Tian, D., and Mino-Kenudson, M. (2012). N. Engl. J. Med. 366, 745-755.

In a recent issue of the New England Journal of Medicine, Cho et al. (2012) provided an interesting and very comprehensive description of an alcoholdependent patient affected by alcoholic liver disease with fibrosis, brain abscess due to toxoplasma, and advanced HIV infection. This case report is a good reminder of three important clinical issues, i.e. (a) HIV-infected alcoholic patients drink more than the general population, alcohol is their most commonly abused drug and contributes to HIV-related morbidity, mortality, and transmission (Fenton et al., 2010); (b) HIV-infected alcoholic patients often have hepatic impairment because of alcohol's effects on liver, HCV coinfection, and antiretroviral therapy (ART)-related hepatotoxicity risk (Szabo and Zakhari, 2011); indeed, alcohol alone, like in this patient (Cho et al., 2012), can be harmful enough to develop clinically significant ALD - notably, in this patient ALD delayed ART initiation (Cho et al., 2012), which may have contributed to further clinical deterioration; (c) Alcohol interventions are dramatically needed for HIV-infected patients. This patient had declined treatment, e.g., disulfiram (Cho et al., 2012), a drug that itself might cause liver failure (Edwards et al., 2011). Though preliminary research is searching for safer and more effective pharmacotherapies (e.g., Addolorato et al., 2007; Johnson et al., 2008; Leggio et al., 2011, 2012), this case (Cho et al., 2012) highlights the need to identify novel pharmacotherapies for alcoholic patients with ALD in order to provide effective interventions that both promote abstinence and help prevent progression to hepatic failure and death.

\section{REFERENCES}

Addolorato, G., Leggio, L., Ferrulli, A., Cardone, S. Vonghia, L., Mirijello, A., Abenavoli, L., D’Angelo, C., Caputo, F., Zambon, A., Haber, P. S., and Gasbarrini, G. (2007). Effectiveness and safety of baclofen for maintenance of alcohol abstinence in alcohol-dependent patients with liver cirrhosis: randomised, double-blind controlled study. Lancet 370, 1915-1922.

Cho, T. A., Larvie, M., Tian, D., and Mino-Kenudson, M. (2012). Case records of the Massachusetts General Hospital. Case 6-2012. A 45-year-old man with a history of alcohol abuse and rapid cognitive decline. $N$. Engl. J. Med. 366, 745-755.

Edwards, S., Kenna, G. A., Swift, R. M., and Leggio, L. (2011). Current and promising pharmacotherapies, and novel research target areas in the treatment of alcohol dependence: a review. Curr. Pharm. Des. 17, 1323-1332.
Fenton, M., Leggio, L., Kenna, G. A., and Swift, R. M. (2010). HIV testing in hazardous drinking: a survey analysis. Subst. Use Misuse 45, 204-212.

Johnson, B. A., Rosenthal, N., Capece, J. A., Wiegand, F., Mao, L., Beyers, K., McKay, A., Ait-Daoud, N., Addolorato, G., Anton, R. F., Ciraulo, D. A. Kranzler, H. R., Mann, K., O’Malley, S. S., Swift, R. M., Topiramate for Alcoholism Advisory Board, and Topiramate for Alcoholism Study Group. (2008). Improvement of physical health and quality of life of alcohol-dependent individuals with topiramate treatment: US multisite randomized controlled trial. Arch. Intern. Med. 168, 1188-1199.

Leggio, L., Ferrulli, A., Zambon, A., Caputo, F., Kenna, G. A., Swift, R. M., and Addolorato, G. (2012). Baclofen promotes alcohol abstinence in alcohol dependent cirrhotic patients with hepatitis $\mathrm{C}$ virus (HCV) infection. Addict. Behav. 37, 561-564.

Leggio, L., Kenna, G. A., Ferrulli, A., Zywiak, W. H., Caputo, F., Swift, R. M., and Addolorato, G. (2011). Preliminary findings on the use of metadoxine for the treatment of alcohol dependence and alcoholic liver disease. Hum. Psychopharmacol. 26, 554-559.

Szabo, G., and Zakhari, S(2011). Mechanisms of alcoholmediated hepatotoxicity in human-immunodeficiency-virus-infected patients. World J. Gastroenterol. 17, 2500-2506.

Received: 28 March 2012; accepted: 28 March 2012; published online: 17 April 2012.

Citation: Leggio L, Promrat Kand Kenna GA (2012) A call to action: alcohol interventions in $\mathrm{HIV}$-infected patients. Front. Psychiatry 3:35. doi: 10.3389/fpsyt.2012.00035

This article was submitted to Frontiers in Addictive Disorders, a specialty of Frontiers in Psychiatry.

Copyright $\odot 2012$ Leggio, Promrat and Kenna. This is an open-access article distributed under the terms of the Creative Commons Attribution Non Commercial License, which permits non-commercial use, distribution, and reproduction in other forums, provided the original authors and source are credited. 